\title{
RULE OF LAW: AN INITIAL ANALYSIS OF SECURITY OFFENCES (SPECIAL MEASURES) ACT (SOSMA) 2012
}

\author{
Saroja Dhanapal* \\ Johan Shamsuddin Sabaruddin**
}

\begin{abstract}
The term 'Internal Security Act' is often given to a piece of legislation laying down regulations that enable the executive government of a jurisdiction to preserve the internal security of the nation. In some jurisdictions, it authorises the government to arrest and detain individuals without trial. The Malaysian Internal Security Act (ISA) 1960 was originally enacted by the Malaysian government in 1960 under Article 149 of the Malaysian Constitution. However, there were numerous concerns raised as to the implications of this Act at various levels over the years and this led to it being repealed. On 15 September 2011, ISA 1960 was repealed and replaced by the Security Offences (Special Measures) Act 2012. SOSMA 2012 was enacted in answer to the criticism of the ISA 1960 and it does show some positive changes. However, the debate as to the concerns with regards to ISA has not been laid to rest. It is advocated and generally accepted by most people around the world that the nation's emphasis on domestic stability cannot be said to negate the presence of the Rule of Law (RoL). The purpose of this research is to analyse the relatively intriguing new Act, the Security Offences (Special Mesaures) Act 2012 with the specific objective to identify whether it upholds the principles deemed necessary under the RoL.
\end{abstract}

Keywords: internal security, Internal Security Act 1960, Security Offences (Special Measures) Act 2012, rule of law

* Ph,D. candidate (University of Malaya), Taylor's University, e mail: saroja.dhanapal@taylors.edu.my

** University of Malaya, e mail: johans@um.edu.my 


\title{
KEDAULATAN UNDANG-UNDANG: ANALISA AWAL AKTA KESALAHAN KESELAMATAN (LANGKAH-LANGKAH KHAS) 2012
}

\begin{abstract}
ABSTRAK
'Akta Keselamatan Dalam Negeri' adalah nama yang sering diberikan kepada rang undang-undang yang memberikan kerajaan eksekutif kuasa untuk menjaga keselamatan dalaman negara. Dalam sesetengah bidang kuasa, ia memberi kuasa kepada kerajaan untuk menangkap dan menahan individu tanpa perbicaraan. Akta Keselamatan Dalam Negeri Malaysia (ISA) 1960 pada asalnya digubal oleh kerajaan Malaysia pada tahun 1960 di bawah Perkara 149 Perlembagaan Malaysia. Walau bagaimanapun, terdapat banyak kebimbangan yang dibangkitkan mengenai implikasi Akta ini di pelbagai peringkat sejak beberapa tahun dan ini membawa kepada tindakan di mana Akta itu telah dimansuhkan. Pada 15 September 2011, ISA 1960 telah dimansuhkan dan digantikan dengan Akta Kesalahan Keselamatan (Langkah-Langkah Khas) 2012 ataupun SOSMA 2012. SOSMA 2012 telah digubal untuk menjawab kritikan terhadap ISA 1960 dan ia menunjukkan beberapa perubahan positif. Namun, perdebatan tentang ISA 1960 tidak berhenti. Ia dianjurkan dan diterima umum oleh kebanyakan orang di seluruh dunia bahawa penekanan negara terhadap kestabilan dalam negeri tidak boleh mengabakan kehadiran Kedaulatan Undang-Undang (ROL). Tujuan kajian ini adalah untuk menganalisa Akta baru ini iaitu Akta Kesalahan Keselamatan (Langkah-langkah Khas) 2012 dengan objektif khusus untuk mengenal pasti sama ada ia berpegang kepada prinsip-prinsip yang dianggap perlu di bawah ROL.
\end{abstract}

Kata kunci: keselamatan dalam negeri, Akta Keselamatan Dalam Negeri 1960, Akta Kesalahan Keselamatan (LangkahLangkah Khas) 2012, kedaulatan undang-undang

\section{INTRODUCTION}

Providing internal security for its citizen is a crucial responsibility of every state and to uphold this responsibility, most states around the world have enacted laws to protect the country and its citizens against threats from terrorists as well as other threatening acts. Internal security act is one such law where the term refers to a piece of legislation that enables the government of a jurisdiction to preserve 
the internal security of the nation by authorising the government to arrest and detain individuals without trial. The Internal Security Act (ISA 1960) was originally enacted by the Malaysian government in 1960 under Article 149 of the Malaysian Constitution. The purpose of the Act according to the then Deputy Prime Minister, the late Tun Abdul Razak, was firstly to counter subversion throughout the country and, secondly, to enable the necessary measures to be taken on the border area to counter terrorism. ${ }^{1}$ Tunku Abdul Rahman, Malaysia's first Prime Minister, defined the purpose of ISA 1960 as to "be used solely against the communists and never to be used to stifle legitimate opposition and silence lawful dissent. ${ }^{2}$ Tun Hussein Onn, Malaysia's third Prime Minister confirmed that his administration had enforced the Act only with a view to curbing communist activity, and not to repress "lawful political opposition and democratic citizen activity". ${ }^{3}$ Despite these constant assurances, there was concern over its application. Since its enactment, this Act had been scrutinised and debated upon at various levels both locally and internationally. According to SUHAKAM, ${ }^{4}$ the Act violated basic human rights. The concerns in relation to ISA 1960 from the human rights perspective was divided into two categories. First, there was concern in relation to the provisions of ISA 1960. It was alleged that they infringe the principles of human rights and the rule of law ('RoL'). Second, there was concern in relation to the application of the provisions of the ISA 1960. It is asserted that under the ISA 1960, citizens and non-citizens alike have been subjected to arbitrary detention and inhuman or degrading treatment whilst in detention. ${ }^{5}$ For example, in the past, ISA 1960 had been invoked or threatened to be invoked in respect of those alleged to have spread rumours, forged passports, cloned hand phones, breached copyrights, counterfeited coins and documents. There is a significant body of public opinion that ISA 1960 had persistently been used to stifle legitimate opposition

\footnotetext{
"Review of the Internal Security Act 1960", SUHAKAM, accessed January 3, 2013, http://www.suhakam.org.my/wp-content/uploads/2013/12/review-ofthe-ISA-1960.pdf.

2 Khairie Hisyam Aliman. "Okay, so we have Zahid's word..." The Malay Mail, January 29, 2013.

Ibid.

"Review of the Internal Security Act 1960".

Ibid.
} 
and silence lawful dissent. ${ }^{6}$ This is supported by Ramdas Tikamdas ${ }^{7}$ who claimed that since independence, these special powers had in fact become tighter and wider in scope arising from a series of constitutional amendments. These have had the effect of curtailing fundamental liberties and human rights according to international standards. As a result, in 2005, Human Rights Watch stated in a report that 'Malaysia is a country with a developed legal and judicial system that no longer needs the crutch of an antiquated preventive detention system." ${ }^{\prime \prime}$

Since there were numerous concerns raised as to the implications of this Act at various levels over the years, it led to the repeal of the Act. On 15 September 2011, the Prime Minister of Malaysia, Dato Seri Najib Razak said that ISA 1960 will be repealed and replaced by the Security Offences (Special Measures) Act 2012 which was passed by Parliament and given the royal assent on 18 June 2012. Security Offences (Special Measures) Act (SOSMA) 2012 was enacted in answer to the criticisms against the ISA 1960 and there appears to be some positive changes. Under SOSMA 2012, initial police detention is cut to a maximum of 28 days, after which the Attorney-General must decide whether to prosecute and on what charges. On the down side, judicial oversight is notably absent during the first 24 hours of police custody and such absence can be extended to the entire 28-day investigatory period. Spiegel explains why Malaysia's replacement Act for the Internal Security Act "does not go far enough to protect the fundamental rights and freedoms of Malaysians." He reminded that when Malaysian Prime Minister, Dato Seri Najib Razak announced in September 2011 that the country's infamous Internal Security Act (ISA) 1960 would be repealed, he referred to tensions "between national security and personal freedom," and promised that the new "legislation formulated will take into consideration fundamental rights and freedoms." Despite SOSMA 2012's promise to ease incommunicado detention by mandating immediate notification of

6 Malaysia, Malaysian Bar, "Memorandum on the Repeal of Laws relating to Detention without Trial by the Malaysian Bar to the Prime Minister", Dato' Dr. Cyrus Das, (December, 10, 1998), accessed January 3, 2013, http://www.malaysianbar.org. my/press_statements/memorandum_on_the_repeal_of_laws_relating_to_detention without trial.html.

7 Ramdas Tikamdas, "National Security and Constitutional Rights: The Internal Security Act 1960" The Journal of the Malaysian Bar, XXXII No 1 (September 2003), accessed January 3, 2013. http://www.malaysianbar.org.my/index.php.

Human Rights Watch, Detained Without Trial Abuse of Internal Security Act Detainees in Malaysia: September 2005 Vol. 17, No. 9(C).

9 Mickey Spiegel, "Smoke and Mirrors: Malaysia’s "New” Internal Security Act", Asia Pacific Bulletin 167 (2012): 1. 
next-of-kin and access to a lawyer chosen by the suspect, that initial access can be postponed should a higher level police officer considers it prudent; another serious violation of an individual's due process rights. Thus, the debate as to the concerns with regards to ISA 1960 has not been laid to rest.

According to Barber, the rule of law (RoL) asks what it means to be governed by law, rather than by men and he asserts that this deceptively simple enquiry has resulted in a variety of conceptions of the rule of law, generally regarded as of crucial importance to constitutional theory, but their meaning and relationship has remained stubbornly elusive. ${ }^{10} \mathrm{RoL}$ is the requirement that the state provide legal guarantees for rights which uphold the dignity of the individual. It has been generally accepted that the RoL does not have a precise definition, and its meaning can vary between different nations and legal traditions. Generally, however, it can be understood as a legal-political regime under which the law restrains the government by promoting certain liberties and creating order and predictability regarding how a country functions. In the most basic sense, the RoL is a system that attempts to protect the rights of citizens from arbitrary and abusive use of government power. According to Hachez and Wouters, over the last two decades, the RoL has become a totem for those who criticise malfunctioning states and legal systems and lament ensuing chaotic social orders. ${ }^{11}$ They added that it is a beacon for those who promote better-functioning legal systems for improving the relations between the members of a social order.

The most important application of the RoL is the principle that governmental authority is legitimately exercised only in accordance with written, publicly disclosed laws adopted and enforced in accordance with established procedural steps that are referred to as due process. Further, Viljoen, CEO of LexisNexis Pacific asserts that there can be no RoL unless there is access to the basic sources of law. ${ }^{12}$ According to Meyerson, ${ }^{13}$ the RoL is the opposite of the rule of power. It stands for the supremacy of law over the supremacy of individual will.

\footnotetext{
10 Nicholas W. Barber, "Must Legalistic Conceptions of the Rule of Law Have a Social Dimension?," Ratio Juris Vol. 17 No. 4 (December 2004): 474-488.

11 Nicolas Hachez and Jan Wouters, "Promoting the Rule of Law: A Benchmarks Approach" (Leuven Centre for Global Governance Studies Working Paper No. 105 April, 2013): 29.

12 Theuns Viljoen, "There can be no Rule of Law unless there is access to the basic sources of law," last modified 1997, assessed January 6, 2013,http://www.lexisnexis.co.uk/en-uk/about-us/rule-of-law.page -.

13 Denise Meyerson, "The Rule of Law and the Separation of Powers", Macquarie Law Journal 1 Vol 4 (2004): 1.
} 
Dicey, as is well-known, stressed three features of the RoL: the need to curb the conferral of discretionary power on government officials in the interests of certainty and predictability; the ability to seek a remedy in independent courts should the government act illegally; and the importance of equality before the law. ${ }^{14}$ In Church of Scientology $v$ Woodward, Brennan J spoke in just such terms about the role played by judicial review in securing the RoL, saying:

[j] udicial review is neither more nor less than the enforcement of the rule of law of executive action; it is the means by which executive action is prevented from exceeding the powers and functions assigned to the executive by law and the interests of the individual are protected accordingly. ${ }^{15}$

Another key element of the RoL is the principle that disputes should be and appear to be decided according to the law and nothing but the law. ${ }^{16}$ If judges depart from the law on the basis of their personal, moral and political views, we risk judicial lawlessness. And if the adjudication of disputes is influenced by external, political pressures, it becomes impossible to control the exercise of power by the political branches of government. ${ }^{17} \mathrm{Craig},{ }^{18}$ advanced a divide between formal and substantive conceptions of the RoL where he claims that the formal conceptions of the RoL are concerned with the manner in which the law is made, and the shape that it takes while substantive conceptions are additionally concerned with the content of the law, identifying specific rights for individuals within the RoL. Dicey's conception of the RoL has three interconnected elements. The first element of Dicey's RoL demanded that individuals not be punished or penalised save where they had committed a distinct breach of the law. This discussion shades into Dicey's second and third element of the rule of law, which insisted that all, including state officials, were bound by the "ordinary law of the land and amenable to the jurisdiction of the ordinary tribunals" and Dicey also contended that individual rights were better protected by the common law than by constitutional guarantees. ${ }^{19}$

\footnotetext{
$14 \quad$ Ibid.

15 Church of Scientology v. Woodward [1982] HCA 78; 154 CLR 25.

16 Joseph Raz, "The Rule of Law and its Virtue," Law Quarterly Review 195, 201 (1977):93.

17 Denise Meyerson, "The Rule of Law and the Separation of Powers", 3.

18 Paul Craig, "Formal and Substantive Conceptions of the Rule of Law," Public Law 467 (1997): 1.

19 Dicey V Albert. Introductory to the Study of the Law of the Constitution.(USA: Liberty Fund Inc., 1982), 179-180.
} 
In "The Rule of Law and its Virtue", ${ }^{20}$ the constitutional theorist Joseph Raz identified the constituent principles of his conception of the RoL. Raz's conception encompasses the additional requirements of guiding the individual's behaviour and minimising the danger that results from the exercise of discretionary power in an arbitrary fashion, and in this last respect he shares common ground with the great constitutional theorists A. V. Dicey, Friedrich Hayek and E. P. Thompson. From this general conception, he stated that some of the most important principles of the RoL are:

- That law should be prospective rather than retroactive.

- Laws should be stable and not changed too frequently, as lack of awareness of the law prevents one from being guided by it.

- There should be clear rules and procedures for making laws.

- The independence of the judiciary has to be guaranteed.

- The principles of natural justice should be observed, particularly those concerning the right to a fair hearing.

- The courts should have the power to review the way in which the other principles are implemented.

- The courts should be accessible; no man may be denied justice.

- The discretion of law enforcement and crime prevention agencies should not be allowed to pervert the law.

Raz and Dicey's accounts of the RoL contain different answers to two different questions. While Raz's RoL flows from the necessary features of the legal system, Dicey's conception of the RoL was unambiguously a political principle that sought to constrain the powerful - state officials, trade unionists, and the like. Dicey's conception of the RoL lay squarely on the side of political theory. Despite wide use by politicians, judges and academics, the RoL has been described as "an exceedingly elusive notion" ${ }^{21}$ giving rise to a "rampant divergence of understandings ... everyone is for it but have contrasting convictions about what it is." ${ }^{22}$ A recent definition of RoL was given by the Council of the International Bar Association which passed a resolution in 2009 endorsing a substantive or "thick" definition of the RoL:

An independent, impartial judiciary; the presumption of innocence; the right to a fair and public trial without undue delay; a rational

\footnotetext{
20 Joseph Raz, "The Rule of Law and its Virtue," 195.

21 Tamanaha Brian, On the Rule of Law: History, Politics, Theory, (Cambridge University Press, 2004), accessed January 5, 2014, http://assets. cambridge.org/97805218/43621/frontmatter/9780521843621_frontmatter.pdf 22 Ibid.
} 
and proportionate approach to punishment; a strong and independent legal profession; strict protection of confidential communications between lawyer and client; equality of all before the law; these are all fundamental principles of the Rule of Law. Accordingly, arbitrary arrests; secret trials; indefinite detention without trial; cruel or degrading treatment or punishment; intimidation or corruption in the electoral process, are all unacceptable. The Rule of Law is the foundation of a civilised society. It establishes a transparent process accessible and equal to all. It ensures adherence to principles that both liberate and protect. The IBA calls upon all countries to respect these fundamental principles. It also calls upon its members to speak out in support of the Rule of Law within their respective communities. ${ }^{23}$

According to the World Justice Project (WJP), a non-profit organisation committed to advancing the rule of law around the world, RoL refers to a rules-based system where four universal principles are upheld:

The government and its officials and agents are accountable under the law; The laws are clear, publicized, stable, fair, and protect fundamental rights, including the security of persons and property; The process by which the laws are enacted, administered, and enforced is accessible, fair, and efficient; Access to justice is provided by competent, independent, and ethical adjudicators, attorneys or representatives, and judicial officers who are of sufficient number, have adequate resources, and reflect the makeup of the communities they serve. ${ }^{24}$

The WJP has developed an Index to measure the extent to which countries adhere to the RoL in practice. The WJP RoL Index is composed of 9 factors and 52 sub-factors, and covers a variety of dimensions of the RoL - such as whether government officials are accountable under the law, and whether legal institutions protect fundamental rights and allow ordinary people access to justice. In the past decade, 'Rule of Law' (RoL) has emerged as a key requirement in the reconstruction of conflict-affected states. No longer simply a philosophical ideal, RoL now exists as a tangible set of policies created and implemented by international actors, to which conflict-affected states are expected to conform.

The purpose of this research is to analyse the issues concerning the RoL in Malaysia's new internal security Act (SOSMA 2012) to

23 Resolution of the Council of the International Bar Association of October 8, 2009, on the Commentary on Rule of Law Resolution (2005)

24 Agrast Mark, Juan Botero, and Alejandro Ponce, "WJP Rule of Law Index" (Washington, D.C.: The World Justice Project, 2011), 8. 
identify as to whether SOSMA 2012 contravenes the virtues of RoL. The research is crucial as the RoL is a key requisite and it subsists as a perceptible set of policies created and implemented by international actors, to which states are expected to conform to promote human rights and to stop the arbitrariness of power in the context of an ever growing social intricacy and globalisation. The inherent difficulties in conducting research on laws governing internal security have resulted in a dearth of academic literature pertaining to the subject. According to De Castro, at one point, issues relating to human rights concerns used to dominate any discussion regarding ISA 1960; however, today, the spectre of international terrorism has vindicated the use of harsh national security legislation by governments, and drowned out demands for such legislation to be abolished based solely on human rights or civil libertarian concerns. In line with this change in the environment and the changing perception on these laws, it is highly crucial for research to be conducted on the new law, SOSMA 2012 which was recently enacted. It is hoped that the findings will play a critical role in the nation's decision to pursue an amendment or to repeal the Act. Further, the findings of the research will add to the knowledge and understanding of the need to balance laws protecting national security with those protecting basic human rights as upheld in the RoL.

\section{RESEARCH METHODOLOGY}

McConville and Wing ${ }^{25}$ divided legal research into doctrinal and non-doctrinal research. Non-doctrinal research can be qualitative or quantitative while doctrinal is qualitative since it does not involve statistical analysis of the data. This research uses a non-doctrinal qualitative research. Since the purpose of this research is to outline an existing legal problem which would lead to legal reform, an analytical and historical approach will be adopted in the study. Analytical approach involves a careful examination and evaluation of an Act in order to understand or explain it or draw inference from it while an historical approach is to understand how and why a certain Act has come to take its particular form to see whether any further changes in the law needs to be made. ${ }^{26}$ In line with this, the researchers will analyse SOSMA 2012 by collecting case laws to not only show how the

25 McConville, M. and Wing, H. C, eds. Research Methods for Law, (Edinburgh: Edinburgh University Press, 2007): 24.

26 Anwarul Yaqin, Legal Research and Writing, (Malaysia: Dolphin Press Sdn. Bhd. 2007), 3 . 
law is not working but also to show the procedural problems involved to highlight the need for possible amendment, repeal or enactment of a new law. The researchers will carry out an in-depth document analysis of the Security Offences (Special Measures) Act 2012 in line with the principles of the Rule of Law as listed by Joseph Raz using the conceptual framework shown in Figure 1.

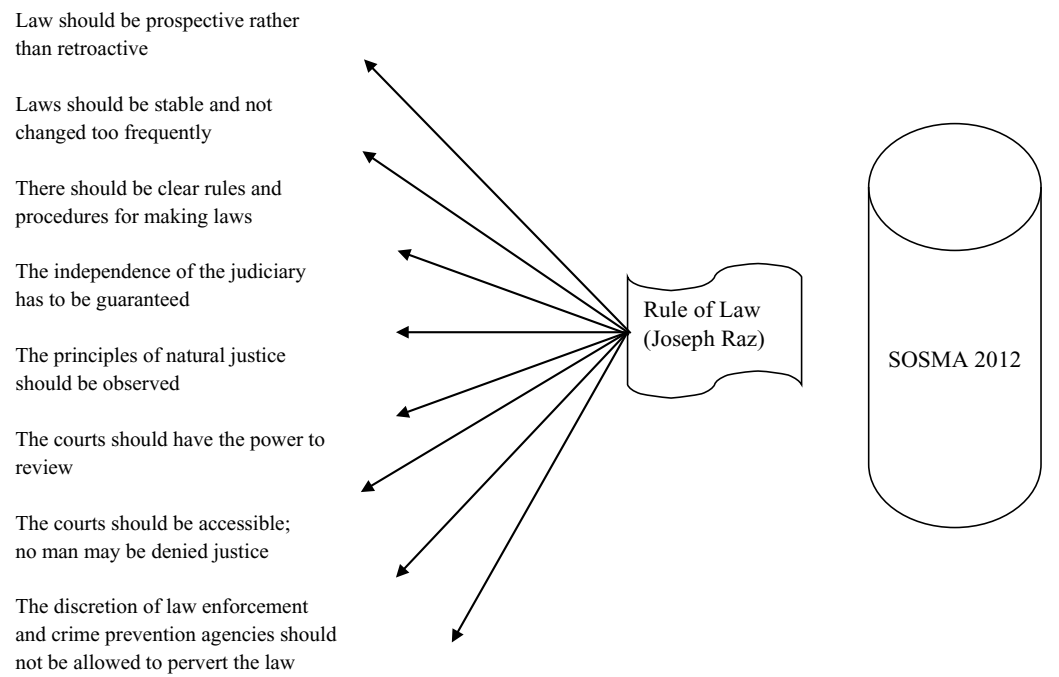

Figure 1. Conceptual Framework

\section{FINDINGS}

\section{Analysis of SOSMA 2012}

According to Brown, ${ }^{27}$ the year 2012 in Malaysia was one of expectations: expectations of reform, set in place by the Prime Minister, Dato Seri Najib Tun Razak's National Day speech in 2011 when he had committed his government to a swath of legal reform among which the most noteworthy was his promise to replace the notorious Internal Security Act (ISA) 1960 which allowed for effectively limitless detention without trial on the order of the Home Minister. The Security Offences (Special Measures) Act 2012, gazetted on the 22nd of June 2012 is to provide for special measures relating to security offences for the purpose of maintaining public order and

27 Brown Graham K, "Malaysia in 2012: Promises of Reform; Promises Met?," Southeast Asia Affairs (January 1, 2013): 153-167. 
security. It is a direct replacement for the Internal Security Act (ISA) 1960. According to the Prime Minister, Datuk Seri Najib Razak, the reform, including the rescinding of three emergency proclamations, ushers in a "new era" for Malaysia. He said the government would no longer limit individuals' freedom but instead ensure their basic constitutional rights were protected. He also hoped other promised reforms, including the introduction of the Peaceful Assembly Act and amendments to the Universities and University Colleges Act, would herald a "golden democratic age in Malaysia." 28 However, the issue in contention here is that the intention of the Act is irrelevant if it becomes open for abuse owing to the fact it is loosely worded and provides for detention without trial, an archaic concept which is deemed out of place in a modern democracy. ${ }^{29}$

According to Tan Sri Abdul Sri Abdul Gani Patail, ${ }^{30}$ alongside the enactment of this legislation, major amendments to the Penal Code and Criminal Procedure Code were also made. The amendments to the Penal Code provide for new offences including activity detrimental to parliamentary democracy, sabotage, espionage and organised crime as well changes to the existing provisions on conspiracy. This is confirmed in Carre' ${ }^{31}$ words where she asserts that the amendments of the Penal Code, coming along with SOSMA 2012 extend the list of security offences where "any activity detrimental to parliamentary democracy" is now considered a security offence, and making the printing and distribution of documents opposed to the government, a threat to national security. Amendments were also proposed to the Criminal Procedure Code to bring it in line with the provisions of SOSMA 2012. These amendments principally touch on interception, definition of 'communication', search and seizure without warrant, attachment of an electronic monitoring device, meaning of an electronic monitoring

28 Ding Jo-Ann, "False hope in Security Offences Act" The NUTGRAPH, April 23, 2012.

29 KPUM, "Law Today: Security Offences (Special Measures) Act 2012 [SOSMA]," March 9, 2014, accessed December 29, 2013, http://www.kpum. org/2014/03/law-today-security-offences-special-measures-act-2012-sosma/.

30 Abdul Gani Patail, "Transforming the Legal Landscape: Public Safety Initiative" Keynote Speech (2013), Midas Talk 6/2013, accessed December 29, 2013, http://www.ilkap.gov.my/nlc2013/download/ Nota/D1KeynoteTSAG.pdf.

${ }_{31}$ Florence Carre, "Malaysia keeps ruling under controversial security laws in secret," April 4, 2013, accessed January 3, 2014, http://www. lejournalinternational.fr/Malaysia-keeps-ruling-under-controversial-securitylaws-in-secret_a1131.html. 
device and access to computerised data. The Code was amended to introduce 13 new offences into Chapter VI (Offences Against the State). Seven of these are new offences namely activity detrimental to parliamentary democracy, attempt to commit activity detrimental to parliamentary democracy, dissemination of information, sabotage, attempt to commit sabotage, espionage and attempt to commit espionage. Sections 124D, 124E, 124F, 124G, 124I and 124J deal with offences which used to be in the Internal Security Act 1960 but with modifications.

Spiegel ${ }^{32}$ explains why Malaysia's replacement Act for the Internal Security Act "does not go far enough to protect the fundamental rights and freedoms of Malaysians". He reminded that when the Malaysian Prime Minister, Dato Seri Najib Razak announced last September that the country's infamous Internal Security Act (ISA) 1960 would be repealed, he referred to tensions "between national security and personal freedom," and promised that the new "legislation formulated will take into consideration fundamental rights and freedoms". Despite SOSMA 2012's promise to ease incommunicado detention by mandating immediate notification of next-of-kin and access to a lawyer chosen by the suspect, that initial access can be postponed should a higher level police officer consider it prudent; another serious violation of an individual's due process rights. ${ }^{33}$ Critics have propounded that SOSMA 2012 is in fact, "old wine in a new bottle" since it still allowed detention without trial and incommunicado detention. ${ }^{34}$ The day SOSMA 2012 was passed in Dewan Rakyat, Home Minister Hishammuddin Hussein asked for a grace period of one week to study the files personally to determine if the remaining ISA 1960 detainees will be tried in court or released. ${ }^{35} \mathrm{He}$ also dismissed the need for a truth commission, saying that it is an effort to distract the public and instill anger and hatred while admitting that there were instances when the Act was used for political reasons. ${ }^{36}$ This shows that the debate as to the concerns relating to the ISA 1960 has not been laid to rest. Thus there is a crucial need to evaluate the rules in SOSMA 2012 to identify if they are aligned to the principles of RoL to uphold fundamental human rights.

In his book 'The Rule of Law and its virtue', Joseph Raz ${ }^{37}$ asserts

\footnotetext{
32 Mickey Spiegel, "Smoke and Mirrors: Malaysia's "New" Internal Security Act" Asia Pacific Bulletin (2012): 167: 1.

33 Ibid.

34 "Malaysia Human Rights Report 2012: Civil and Political Rights". (SUARAM Komunikasi, 2013), 2.

Ibid, 5.

Ibid.

37 Joseph Raz, The Authority of Law: Essays on Law and Morality, (UK: Clarendon
} 
that the law must be capable of guiding the behaviour of its subjects and he went on to list 8 specific principles that can be derived from the basic idea of RoL. These principles include: all laws should be prospective, open, and clear; laws should be stable; the making of laws should be guided, open, clear, and general rules; the independence of the judiciary must be guaranteed; natural justice must be observed; courts must have reviewing power over some principles; courts should be accessible; and the discretion of crime-preventing agencies should not be allowed to pervert the law. ${ }^{38}$ With regards to these principles, SOSMA 2012 can be analysed in two ways; firstly through the words and phrases used in the Act to describe the law under the respective sections and secondly, through the implementation of the laws under the Act when arrests are made and brought for hearing before the courts. The analysis of SOSMA 2012 in accordance to Raz's principles is shown in Table 1.

TABLE 1:

Analysis of SOSMA 2012 with the Principles of the Rule of Law

\begin{tabular}{|c|c|c|}
\hline No. & $\begin{array}{c}\text { Principles of Rule } \\
\text { of Law (Joseph } \\
\text { Raz) }\end{array}$ & Sections in SOSMA 2012 \\
\hline 1 & $\begin{array}{l}\text { Law should be } \\
\text { prospective rather } \\
\text { than retroactive }\end{array}$ & -NA- \\
\hline 2 & $\begin{array}{l}\text { Laws should be } \\
\text { stable and not } \\
\text { changed too } \\
\text { frequently }\end{array}$ & $\begin{array}{l}\text { S } 4 \text { (11)-Subsection (5) shall be reviewed } \\
\text { every five years and shall cease to have effect } \\
\text { unless, upon the review, a resolution is passed } \\
\text { by both Houses of parliament to extend the } \\
\text { period of operation of the provision. }\end{array}$ \\
\hline 3 & $\begin{array}{l}\text { There should be } \\
\text { clear rules and } \\
\text { procedures for } \\
\text { making laws }\end{array}$ & -NA- \\
\hline 4 & $\begin{array}{l}\text { The independence } \\
\text { of the judiciary } \\
\text { has to be } \\
\text { guaranteed }\end{array}$ & $\begin{array}{l}\text { Section } 11 \text { of the Act provides that no courts may } \\
\text { compel the Public Prosecutor to produce any } \\
\text { statements that contain sensitive information } \\
\text { or summary of the sensitive information if the } \\
\text { Home Minister certifies that the production } \\
\text { of the statement or summary is prejudicial to } \\
\text { national security or national interest. }\end{array}$ \\
\hline
\end{tabular}

Press, 1979), 214-218.

38 Ibid. 


\begin{tabular}{|c|c|c|}
\hline 5 & $\begin{array}{l}\text { The principles } \\
\text { of natural justice } \\
\text { should be } \\
\text { observed }\end{array}$ & $\begin{array}{l}\text { S } 8 \text { (1) Notwithstanding section } 51 \mathrm{~A} \text { of the } \\
\text { Criminal procedure code, if the trial of a } \\
\text { security offence involves matters relating to } \\
\text { sensitive information the public prosecutor } \\
\text { may, before the commencement of the trial, } \\
\text { apply by way of an ex parte application to } \\
\text { the court to be exempted from the obligations } \\
\text { under section } 51 \text { A of the criminal procedure } \\
\text { code. } \\
\text { S } 8 \text { (2) The public prosecutor shall disclose } \\
\text { to the court the intention to produce sensitive } \\
\text { information as evidence against the accused } \\
\text { during the trial and the court shall allow the } \\
\text { application under subsection (1). } \\
\text { S } 9 \text { (1) If an accused reasonably expects to } \\
\text { disclose or to cause the disclosure of sensitive } \\
\text { information in any manner, in his defense, } \\
\text { the accused shall give two days' notice to the } \\
\text { public prosecutor and the court in writing of } \\
\text { his intention to do so. } \\
\text { S } 23 \text { The non-production of the actual exhibit } \\
\text { protected under Section } 8 \text { and } 11 \text { shall not be } \\
\text { prejudicial to the prosecution's case } \\
\mathrm{S} 30 \text { (1) Notwithstanding Article } 9 \text { of the } \\
\text { Federal Constitution, if the trial court acquits } \\
\text { an accused of a security offence the public } \\
\text { prosecutor may make an oral application to } \\
\text { the court for the accused to be remanded in } \\
\text { prison pending a notice of appeal to be filed } \\
\text { against his acquittal by the public prosecutor. }\end{array}$ \\
\hline 6 & $\begin{array}{l}\text { The courts should } \\
\text { have the power to } \\
\text { review }\end{array}$ & $\begin{array}{l}\text { S } 4 \text { (4) The person arrested and detained } \\
\text { under subsection (1) may be detained for a } \\
\text { period twenty-four hours for the purpose of } \\
\text { investigation } \\
\text { S } 4 \text { (5)Notwithstanding subsection (4), a police } \\
\text { officer of or above the rank of Superintendent } \\
\text { of police may extend the period of detention } \\
\text { for a period of not more than twenty-eight } \\
\text { days, for the purpose of investigation }\end{array}$ \\
\hline
\end{tabular}




\begin{tabular}{|c|c|c|}
\hline 7 & $\begin{array}{l}\text { The courts should } \\
\text { be accessible; } \\
\text { no man may be } \\
\text { denied justice }\end{array}$ & $\begin{array}{l}\text { S } 5 \text { (2) A police officer not below the rank } \\
\text { of Superintendent of police may authorize a } \\
\text { delay of not more than forty-eight hours for } \\
\text { the consultation under paragraph (1) (b) if } \\
\text { he is of the view that - there are reasonable } \\
\text { grounds for believing that the exercise of that } \\
\text { right will interfere with evidence connected to } \\
\text { security offence; } \\
\text { (a) there are reasonable grounds for } \\
\text { believing that the exercise of that } \\
\text { right will interfere with evidence } \\
\text { connected to security offence; } \\
\text { (b) it will lead to harm to another; } \\
\text { (c) it will lead to the alerting of other } \\
\text { person suspected of having committed } \\
\text { such an offence but who are not yet } \\
\text { arrested; or } \\
\text { (d) it will hinder the recovery of property } \\
\text { obtained as a result of such an offence. } \\
\text { S } 5 \text { (3) This section shall have effect } \\
\text { notwithstanding anything inconsistent with } \\
\text { Article } 5 \text { of the Federal Constitution. }\end{array}$ \\
\hline 8 & $\begin{array}{l}\text { The discretion of } \\
\text { law enforcement } \\
\text { and crime } \\
\text { prevention } \\
\text { agencies should } \\
\text { not be allowed to } \\
\text { pervert the law }\end{array}$ & $\begin{array}{l}\text { S 6 (3) Notwithstanding subsection (1), a police } \\
\text { officer not below the rank of Superintendent } \\
\text { of police may-intercept, detain and open any } \\
\text { postal article in the course of transmission } \\
\text { by post; intercept any message transmitted } \\
\text { or received by any communication; or } \\
\text { intercept or listen to any conversation by any } \\
\text { communication, without authorization of the } \\
\text { public prosecutor in urgent and sudden cases } \\
\text { where immediate action is required leaving no } \\
\text { moment of deliberation. } \\
\text { S } 6 \text { (4) If a police officer has acted under } \\
\text { subsection (3), he shall immediately inform } \\
\text { the public prosecutor of his action and he } \\
\text { shall then be deemed to have acted under the } \\
\text { authorization of the public prosecutor. }\end{array}$ \\
\hline
\end{tabular}




\begin{tabular}{|c|c|c|}
\hline & & $\begin{array}{l}\text { S } 24 \text { Where a person is charged for a security } \\
\text { offence, any information obtained through an } \\
\text { interception of communication under section } 6 \\
\text { shall be admissible as evidence at his trial and } \\
\text { no person or police officer shall be under any } \\
\text { duty, obligation or liability or be in any manner } \\
\text { compelled to disclose in any proceedings the } \\
\text { procedure, method, manner or any means or } \\
\text { devices, or any matter whatsoever with regard } \\
\text { to anything done under section } 6 \text {. } \\
\text { S } 31 \text { The Minister may make regulations as } \\
\text { may be necessary or expedient for giving full } \\
\text { effect to or for carrying out the provisions of } \\
\text { this Act. }\end{array}$ \\
\hline
\end{tabular}

The researchers maintain that to establish whether SOSMA 2012 adheres to the first principle that laws should be prospective, open and clear and the third principle that the making of laws should be guided, open and clear can only be determined through the analysis of how the law is used to maintain public order and security that is through the implementation of the law itself. The second principle which calls for laws to be stable and not changed too frequently is crucial. According to Hayak, ${ }^{39}$ RoL means that the government in all its actions is bound by rules fixed and announced beforehand which ensures that the people can foresee with certainty how the authority will use its coercive powers in given circumstances, and to plan one's individual affairs on the basis of this knowledge. Raz claims that if laws are frequently changed, people will find it difficult to find out what the law is at any given moment and will be constantly in fear that the law has been changed since they last learnt what it was. He adds that it is more important for people to know the law not only for short-term decisions but also for long-term planning. ${ }^{40}$ SOSMA 2012, however, is seen to lack stability as section 4 (11) states that subsection (5) shall be reviewed every five years and shall cease to have effect unless, upon the review, a resolution is passed by both Houses of Parliament to extend the period of operation of the provision. The fact that it makes the review mandatory in itself removes the element of stability in the law. Some might interpret this section positively indicating that the provision to extend the duration of not allowing the accused accessibility to legal consultation can be removed

39 Hayak, cited in Joseph Raz, The Authority of Law: Essays on Law and Morality, (UK: Clarendon Press, 1979), 210.

40 Joseph Raz, The Authority of Law, 214-215. 
by way of review but then it also raises the concern that the duration can also be increased through the same review process. Ultimately, the section that removes the stability of the law with regards to the duration of the remand period can lead to arbitrary detention which was one of the criticisms raised against ISA 1960.

Joseph Raz's fourth principle that the independence of the judiciary has to be guaranteed is also questionable in SOSMA 2012. Section 11 of the Act provides that no courts may compel the Public Prosecutor to produce any statements that contain sensitive information or summary of sensitive information if the Home Minister certifies that the production of the statement or summary is prejudicial to national security or national interest. This section indicates the weakness in the law as the judiciary lacks the power to compel the production of the statements in a hearing and the decision to determine its sensitivity lies in the power of the Home Minister. This section removes the independence of the judiciary and it is contradictory to the principle of separation of powers that Malaysia claims to uphold. According to Kelly, ${ }^{41}$ the actual separation of powers amongst different branches of government can be traced to ancient Greece where the governmental system is based on the idea of three separate branches: executive, judicial, and legislative so that the three branches are distinct and have checks and balances on each other to ensure no one branch can gain absolute power or abuse the power they are given.

Further breaches of the RoL are seen in the principle of upholding natural justice. This can be noted in sections 8,9 and 30 (1). These sections are clear indications that SOSMA 2012 does not uphold the principles of natural justice. Section 8 and Section 9 must be read together to understand the implications on natural justice. The provisions are related to the submission of sensitive information. According to section 8 (1), if the trial of a security offence involves matters related to sensitive information, the Public Prosecutor can apply to the court to be exempted from the obligation to produce such information. Section 8 (20) further allows the Public Prosecutor to produce sensitive information by merely disclosing the intention to do so to the courts. However, in the case of the accused, section 9 stipulates that the accused needs to give two days' notice to the Public Prosecutor and the court in writing. These different requirements for the Public Prosecutor and the accused for the same matter are clear indications of a violation of natural justice. Section 23 further states that the nonproduction of the actual exhibit protected under sections 8 and 11 shall

41 Martin Kelly, "Separation of Power" assessed August 1, 2014, http:// americanhistory.about.com/od/usconstitution/g/sep_of_powers.html. 
not be prejudicial to the prosecution's case. In addition, S 30 (1), states that the Public Prosecutor may make an oral application to the court for the accused to be remanded in prison pending a notice of appeal to be filled in cases where the trial court has acquitted an accused of a security offence. This imprisonment can go on for an indefinite period as long as the appeal is in effect. Ding Jo-Ann ${ }^{42}$ criticises this section of SOSMA 2012 as the imprisonment can be indefinite for the length of time it takes for appeals to be heard varies in this country and she cited the Home Ministry's appeal against the December 2009 High Court decision on The Herald's use of "Allah" which was only heard in 2013 as evidence. Thus, this section raises the possibility for a person acquitted under SOSMA 2012 to be imprisoned for an indefinite time pending appeal.

The sixth and seventh principle of Joseph Raz can be discussed collectively as it discusses the court's power to review and the accessibility of the court to an accused. Section 4 limits the power of the court to review a case as it allows the detention without trial to be extended to twenty-eight days. Further sections 5 (2) and 5 (3) limit the accused's right to legal counsel. According to the Deputy Home Minister Datuk Wan Junaidi Tuanku Jaafar, ${ }^{43}$ investigations under the security offences were time consuming and the maximum of 28 days' detention provided by the Security Offences (Special Measures) Act 2012 was insufficient. However, Suruhanjaya Hak Asasi Manusia (SUHAKAM) ${ }^{44}$ in its 2012 annual report highlighted further problems in relation to the Act whereby Section 4 of the Act does not provide for judicial oversight owing to the detention without trial being allowed to be extended to twenty-eight days. The new security law certainly underwrites the right to a fair trial and appeal proceedings. ${ }^{45}$ Furthermore, Section 5 allows the police to deny immediate access to legal representation for up to forty-eight hours. Under section 5 (2), a police officer not below the rank of a Superintendent of Police may delay the right to consult legal advice under section 5(1) (b) to not more than 48 days if he believes that one of the conditions laid down in section 5 (2) (a) to (d) would be triggered. Section 5 (3) gives overriding power to this section as it is stipulated that the section would have effect in spite of anything inconsistent with Article 5 of the

\footnotetext{
42 Ding Jo-Ann, "False Hope in Security Offences Act".

43 "108 nabbed under Sosma," New Straits Times Online, July 2, 2014,

44 KPUM, "Law Today: Security Offences".

45 Florence Carre, "Malaysia keeps ruling under controversial".
} 
Federal Constitution. Raz ${ }^{46}$ asserts that long delays, excessive costs, etc., may effectively turn the most enlightened law to a dead letter and frustrate one's ability effectively to guide oneself by the law.

The last principle stated by Joseph Raz in RoL is that the law enforcement and crime prevention agencies should not be allowed to pervert the law. It is evident that this principle is absent in SOSMA 2012 if sections 6 (3), 6(4), 24 and 31 are analysed. Section 6 (3) empowers a police officer not below the rank of superintendent of police to intercept communication without the authorisation of the Public Prosecutor in urgent and sudden cases. Section 6 (4) makes the interception as legal where on informing the Public Prosecutor, the court will deem it to be authorised by the Public Prosecutor. The Malaysian Bar Council ${ }^{47}$ is of the opinion that the fact that the Act serves to further erode citizen rights and individual protection by ceding to the police force rather than the judges the power to intercept communications and at trial, keeping the identity of prosecution witnesses classified thus negating cross-examination. This is seen in the recent case of PP v. Hassan Hj. Ali Basri. ${ }^{48}$ In general, the evidence of a protected witness shall be given in such manner that he would not be visible to the accused and his counsel, but would be visible to the court; and if the witness fears that his voice may be recognised, his evidence shall be given in such manner that he would not be heard by the accused and his counsel. The court may also disallow such questions to be put to the witness as to his name, address, age, occupation, race or other particulars or such other questions as in the opinion of the court would lead to the witness's identification. Section 28 of the Act provides for the identity of the informer to be equally protected. No record that may compromise the identity of a protected witness may be allowed to be made. Any breach of this provision may result in a custodial sentence for a term of not more than 5 years and shall also be liable to a fine of not more than RM10,000.00. In PP v. Hassan Hj. Ali Basri, Kpl Hassan, an Royal Malaysia Police (RMP) personnel attached to the Special Branch (SB) and a Semporna local was charged under section 130M of the Penal Code for hiding information relating to the impending intrusion by the so-called "Royal Sulu Sultanate Army" in Kampung Tanduo, Lahad Datu, Sabah and the High Court Judge had granted "protected witness" status to two prosecution witnesses who were thenceforth known as Protected Witness No. 1 (P.W. 1) and Protected Witness No. 2 (P.W. 2). The Judge also made the following ruling:

\footnotetext{
46 Joseph Raz, The Authority of Law: Essays on Law, 217.

47 KPUM, "Law Today: Security Offences".

$48 \quad$ [2014] 7 MLJ 1536.
} 
I deliberately did not record the questions I posed to the witnesses or their answers during the inquiry in the notes of proceedings as that could give clues to their identity. It should be noted that even during cross examination, questions that could lead to the identification of a protected witness are barred (see section 14(4) of the SOSMA). This procedure was adopted in order to comply with section 14(3). ${ }^{49}$

Kpl. Hassan was found guilty on $6^{\text {th }}$ of August, 2013 and was sentenced to seven years imprisonment by the High Court in Kota Kinabalu. Further, under section 24, any information obtained through an interception of communication under section 6 is said to be admissible as evidence and no person or police officer can be compelled to disclose such evidence where a person is charged for a security offence. In addition, section 31 empowers the Minister to make regulations as may be necessary or expedient for giving full effect to or for carrying out the provisions of this Act.

\section{CASES UNDER SOSMA 2012}

Initially, with SOSMA 2012 being gazetted, it was generally perceived that when the new Act comes into force, it would really open up room for real justice based on principles stated in ROL. But in reality this did not happen. The detention orders made against the 45 detainees held under ISA 1960 was still valid under section 32 of SOSMA 2012. The section stipulates that the repeal of the ISA 1960 shall not affect any order issued or made under the repealed ISA prior to the date of coming into operation of SOSMA, unless earlier revoked by the Minister; and any action or proceedings taken under the repealed ISA prior to the date of coming into operation of SOSMA..$^{50}$ Besides, this restraint under section 32, there are other issues of concern with regards to the new Act. Firstly, it must be accepted that the new security law fails to meet international standards on several key aspects. An analysis of the terms used in the Act proves this. For example, the definition of a security offence is particularly vague since it is described as "action [...] which is prejudicial to public order in, or the security of, the Federation or any part thereof," -which leaves a relatively substantial margin of interpretation to executive power. ${ }^{51}$ This is confirmed by the

\footnotetext{
$49 \quad$ Public Prosecutor v. Hassan bin Haji Ali Basari. [2013] 1 LNS 717.

50 SY New, “And We Thought It Was All Over," last revised July 9, 2012, accessed December 29, 2013, http://www.loyarburok.com/2012/07/09/thought/.

51 Florence Carre, "Malaysia keeps ruling under controversial".
} 
Bar Council of Malaysia where it is stated that the Security Offences (Special Measures) Act 2012 (SOSMA 2012) contains an extremely wide definition of what constitutes a "security offence." 52 In addition, it allows for an initial detention of 24 hours by the police to be extended for up to 28 days if authorised by a police officer above the rank of superintendent, without any supervision by the courts. In addition, detainees can be denied access to legal counsel for up to 48 hours after arrest.

According to Tan Sri Abdul Gani Patail, Attorney General of Malaysia, ${ }^{53}$ the accusation that SOSMA 2012 which is to replace the Internal Security Act 1960 is just "a new name for ISA 1960" is yet to be proven and the features between the two legislations are certainly different in the sense that SOSMA 2012 provides for safeguards against any abuse of power to make sure that the Act is properly used for its intended purpose and not merely as a political tool that will impede the democratic system in Malaysia. The following discussion will highlight cases under SOSMA 2012 to evaluate whether the law is in line with the principles of the RoL or whether it is just a new name for the ISA 1960 which still disregards basic human rights in the name of national security.

This first arrest under SOSMA 2012 shows that the Malaysian authorities have just replaced an oppressive regime with another. ${ }^{54}$ On 7 February 2013, the government arrested three people under SOSMA 2012. All three were eventually charged and are now awaiting trial. Two were charged within a day, but a third person was detained for 11 days before being granted access to legal counsel. The two men aged 33 and 49 were employees in a cafeteria. They are accused of being members of the Tanzim al-Qaeda Malaysia terrorist organisation, and of having participated in its activities between August 2012 and February 2013. While Yazid Sufaat is charged for promoting terrorism in Syria from Kuala Lumpur, Muhammad Hilmi and his wife are accused of abetting him. What is ironic is that on May 20 last year, High Court Judge Kamardin Hashim ruled that the Act could not be used against the two as it went beyond the scope of Article 149 of the Federal Constitution,

\footnotetext{
$52 \quad$ Malaysian Bar Council, "Submission of Bar Council Malaysia for the Universal Periodic Review of Malaysia," last modified March 11, 2013, 1, accessed December 29, 2013, http://www.malaysianbar.org.my/index.php?option=com_docman\&task=doc view\&gid $=4096$.

53 Abdul Gani Patail, " Transforming the Legal Landscape".

54 Florence Carre, "Malaysia keeps ruling under controversial".
} 
which covered only domestic terrorism. ${ }^{55}$ Tan Sri Abdul Gani Patail ${ }^{56}$ claims that the new law is in line with the vision to guarantee public safety in the nation and the law formulated took into account basic rights and freedom based on the Federal Constitution. He went on to add that the Government has given its commitment that no individual will be detained purely based on political ideology. ${ }^{57}$ However, the public view it differently. According to Carre ${ }^{58}$ Amnesty International called the law "oppressive" and Isabelle Arradon, ${ }^{59}$ Amnesty International's Deputy Asia-Pacific Director asserted that "Sufaat and Hasim are being detained arbitrarily under a deeply flawed law that is not in line with international human rights standards." This perception is further supported by Surendran ${ }^{60}$ who asserts that in its effect, SOSMA 2012 is similar to the ISA 1960 as no bail is allowed pending trial and appeals. He added that through SOSMA 2012, the government has re-introduced the ISA 1960 through the back door. He supported his claim by citing the arrest of SAMM political activist Saiden, which he says poses a grave danger to the rule of law and the liberties of all Malaysians. He concludes that once again Malaysians are under threat of long-term detention solely for carrying on legitimate political activities. He went on to proclaim that the Malaysian authorities should not compromise human rights in the name of security and should immediately revise or repeal the new security law. ${ }^{61}$ Contrary to this, Attorney-General (AG) Tan Sri Abdul Gani Patail ${ }^{62}$ lamented that SOSMA 2012 is drafted in such way that only in special circumstances bail can be granted, but when the court used its discretion in allowing bail application, Halima Hussein took advantage by jumping bail. He went on to state that initially the High Court ruled against the prosecution by releasing her and two others. However, when the court reversed the decision at the Court of Appeal, the accused is no longer in custody.

\footnotetext{
55 Qishin Tariq, "Prosecution wins appeal against Yazid Sufaat's acquittal over terror charge." The Star OnLine, July 15, 2013.

56 Abdul Gani Patail, "Transforming the Legal Landscape".

57 Section 4(3) of the Security Offences (Special Measures) Act 2012 provides that "No person shall be arrested and detained under this section solely for his political belief or political activity."

58 Florence Carre, "Malaysia keeps ruling under controversial".

59 Ibid.

60 Surendran N., "Activist Arrested: Government Using Sosma Against Political Opponents," Aliran, last modifed May 2, 2014, accessed December 292014 , http://aliran.com/civil-society-voices/2014-civil-society-voices/activist-arrestedgovernment-using-sosma-political-opponents/.

61 "Amnesty slams Malaysia arrests under new law," Astro Awani, February 8, 2013.

62 "First woman charged under SOSMA still on the run," The Malay Mail Online, December 18, 2013.
} 
On $5^{\text {th }}$ of March 2013, Malaysian authorities launched additional security operations. Of the 103 detainees resulting from those operations, thirty were eventually charged under Malaysia's Penal Code and SOSMA 2012 for harbouring terrorists (Section 130K), membership of a terrorist group (Section $130 \mathrm{~K}(\mathrm{a})$ ), recruiting terrorists (Section 130E), and waging war against the King (Section 121). Some of these individuals are awaiting trial while the other suspects have been deported, transferred to immigration holds, or released within the 28-day period mandated by SOSMA 2012. In August 2013, a 61-yearold veteran of the Royal Malaysia Police Special Branch unit was sentenced to seven years in prison under SOSMA 2012 for withholding information linked to the Lahad Datu incursion (Country Report 2013). In this incident which took place on $11^{\text {th }}$ of February, approximately 250 armed insurgents, calling themselves the "Royal Security Forces of the Sultanate of Sulu and North Borneo", invaded the Lahad Datu region asserting a claim to the territory. Malaysian security forces engaged in negotiations with the insurgents in an attempt to end the incursion peacefully, and the governments of Malaysia and the Philippines remained in contact at senior levels. However, after several weeks of negotiations, fighting broke out on $1^{\text {st }}$ of March which resulted in the deaths of nine Malaysian police officers, six civilians, and 72 insurgents. The president of Pertubuhan Kebajikan Al-Ehsan, Muhammad Ridzwan Sulaiman, who surrendered at the Ampang district police headquarters to facilitate the Sabah armed intrusion investigation was detained under the Security Offences (Special Measures) Act 2012 (SOSMA 2012) ${ }^{63}$ Tan Sri Abdul Gani Patail explained that SOSMA 2012 facilitated police in carrying out their investigations and the security forces to conduct military operations on the intruders during the Lahad Datu intrusion incident but when the intruders were eventually charged in court under SOSMA 2012, the prosecution only tendered the search list of documents and exhibits seized during the cause of investigation compared with any normal criminal proceedings. ${ }^{64}$ In this conflict, it was alleged that 79 persons have been detained under SOSMA 2012 and this gives cause for concern. No information has been forthcoming from the government as to the identities of these individuals, and whether they have been accorded due process of the law in terms of access to legal representation. ${ }^{65}$

\footnotetext{
63 Priscilla Prasena , "Ridzwan detained under SOSMA," last modified April 1, 2013, assessed December 2, 2013, accessed December 29, 2013,http:/www. freemalaysiatoday.com/category/nation/2013/04/01/wanted-dato-seri-surrendersdenies-involvement/Prasena.

64 "First woman charged under SOSMA still on the run".

65 Malaysian Bar Council, "Submission of Bar Council," 2.
} 
On $15^{\text {th }}$ of November 2013, gunmen, allegedly from the Philippines and linked to the Abu Sayyaf Group, raided a resort on Pom Pom Island off the eastern coast of Sabah, killing a tourist from Taiwan and taking his wife hostage. On $20^{\text {th }}$ of December, Philippine authorities recovered her in a forest near the village of Talipao on the island of Jolo. Some media reports indicated she was released in exchange for a ransom payment. On $2^{\text {nd }}$ of December, the Royal Malaysian Police announced the arrest of two Filipino suspects in Semporna, eastern Sabah, allegedly linked to the attack. ${ }^{66}$ The Malaysian security force arrested three more people who were believed to have links with the Sulu terrorists who invaded East Sabah on $9^{\text {th }}$ of February $2013 .{ }^{67}$ It is also extremely disturbing that the detained person is a member of a group (SAMM) which is a strong critic of the Umno/BN government. It is illegal and unconstitutional for the government to use terror laws against political critics and dissenters. According to Aliran, no evidence whatsoever has been produced linking Saiden with any kind of militant activity and the arrest is shocking. ${ }^{6}{ }^{\text {Section }} 4$ (3) of SOSMA 2012 stipulates clearly that no person is to be arrested and detained "solely for his political belief or political activity". This section was specifically inserted to prevent the government from abusing SOSMA 2012 for political purposes. However, this arrest can be seen to contravene the provision of section 4 (3).

Nine people, including two women, were separately arrested by security forces at several locations in Beluran in 2013, for allegedly conspiring with the armed terrorists in Tanduo village in Lahad Datu, early March. Disclosing this, the then Sabah Police Commissioner Datuk Hamza Taib said seven of those arrested are of Sulu origin from the Philippine, while two are locals ${ }^{69}$ Police arrested six people, including a woman, in Kunak, Sabah, on 25 June 2014 on suspicion of engaging in militant activities. ${ }^{70}$ Inspector-General of Police Tan Sri Khalid Abu Bakar, in a statement, said the suspected Sulu terrorists were arrested during a special operation conducted by the Bukit Aman

\footnotetext{
66 "Malaysia: Risk and Compliance Report", (Know Your Country, December, 2014), 14.

67 T K Letchumy Tamboo "Gun battles continue, 3 more arrested under Sosma," Astro Awani, last modified March 19, 2013.

68 Surendran N., "Activist Arrested: Government Using SOSMA".

69 Aaron Chin, "Nine people arrested in Beluran under SOSMA Nine people arrested in Beluran under SOSMA" Borneo Insider, last modified April 10, 2013.

70 "6 in Sabah held under Sosma," The New Straits Times Online, June 26, 2014.
} 
Special Branch and Eastern Sabah Security Command. The operation was conducted following the Lahad Datu attack in February last year. Khalid said the six were being investigated under the Security Offences (Special Measures) Act 2012 and Section 124 (C) of the Penal Code for committing activities detrimental to parliamentary democracy.

In regards to the 31 December Protest Rally, deputy police chief Amar Singh Ishar Singh ${ }^{71}$ said police would not hesitate to detain parties attempting to spark unrest under the Penal Code and the Security Offences (Special Measures) Act 2012 (SOSMA). The price hike rally was attended by some 10,000 people who were there to voice their dissatisfaction with the rising cost of living and increase in the prices of goods and services. The rally was organised by Gerakan Turun Kos Sara Hidup (Turun), a group committed to reducing cost of living. The former Prime Minister, Dr Mahathir Mohamad condemned the illegal rally held during the New Year's Eve celebration last night, describing the Act as undemocratic. In response to the accusation made by Amar Singh with regards to the rally, Solidariti Anak Muda Malaysia (SAMM), central coordinator, Badrul Hisham Shaharin ${ }^{72}$ or better known as Chegubard, lodged a police report and said the report was the first step before they filed a defamation suit against Amar. Two of his statements ${ }^{73}$ are quoted here as evidence of how it appears to the public that SOSMA 2012 is still being used as a tool to curb political activities:

They (the police) said they recovered weapons, bombs, arrested people for throwing bottles and such. Tell us what happen to them or else it only shows that it is just propaganda created to instill fear among the public"

"We don't want police to become a tool of the government's propaganda. At the time when police energy and effort should be channeled to combat crime, they are being burdened with this kind of investigation.

The most recent call for the use of SOSMA 2012 is seen in the

\footnotetext{
71 "Police issue warning to organisers of New Year's eve rally", The Sun Daily, December 28, 2013, assessed August 13, 2014, www.thesundaily.my/news/915752.

72 Muzliza Mustafa, "Activist lodges report against KL senior cop for 'slanderous' comment," January 20, 2014, assessed August 13, 2014, http://www. themalaysianinsider.com/malaysia/article/activist-lodges-report-against-kl-seniorcop-for-slanderous-comment\#sthash.jJksV1am.dpuf.

73 Ibid.
} 
recent airline crash in Ukraine. Mohd Farhan Darwis ${ }^{74}$ stated that the country's top lawyer (referring to Attorney-General, Tan Sri Abdul Gani Patail) said Malaysia had made clear that it wished to bring the guilty parties to the country and charge them under the Security Offences (Special Measures) Act 2012. The Deputy Home Minister, Datuk Dr Wan Junaidi Tuanku Jaafar had also previously said that under SOSMA 2012, Malaysia has the right to use its own laws to take legal action on any crime against the country, including those committed abroad. Of the 298 people killed in the Kuala Lumpur-bound flight, which took off from Amsterdam on $17^{\text {th }}$ of July, 195 were Dutch nationals and 43 Malaysians. The outcome of this is yet to be seen.

\section{SOSMA AMENDMENT BILL 2015}

An analysis of the SOSMA Amendment Bill 2015 in the Parliament recently must be taken into consideration to identify its implication on the principles upheld in the RoL before a conclusion can be made. If the Bill is analyzed, it will show that most of the amendments have significant implication especially in terms of the principles in the RoL except for the amendment to section 5 (1) (b) where the word 'persons' is substituted with 'person'. This amendment is done to ensure consistency with section 5 (1) (a). However, the amendments made to sections 6, 18, 20, 22 and 24 have serious implication if analysed in relation to the principles upheld in the RoL. Table 2 shows the analysis of these significant sections:

The amendment to Section 6 is in breach of the eight principles of RoL where it is stated by Raz that the discretion of law enforcement and crime prevention agencies should not be allowed to pervert the law. Here, empowering the Public Prosecutor to authorise 'any other person' is not only breaking the rule on separation of powers but also widens the ambit of persons who can intervene in cases investigated under SOSMA 2012 as 'any other person is not defined'. Besides this infringement of the principle in the RoL, the new sections of $18 \mathrm{a}$ and $18 \mathrm{~b}$ also give room for concern. Section $18 \mathrm{a}$ allows any statement by the accused whether orally or in writing to any person at any time to be admissible in evidence. Further, section $18 \mathrm{~b}$ infringes into the sanctity of marriage by compelling a spouse who is or has been

\footnotetext{
74 Mohd Farhan Darwis, "Malaysia will charge suspect who shot down MH17, says A-G," August 8, 2014, assessed August 13, 2014, http:/www.themalaysianinsider. com/malaysia/article/malaysia-will-charge-suspect-who-shot-down-mh17-says-ag1\#sthash.FnLgVn7d.dpuf.
} 
married to disclose any communication made to him during marriage by any person to whom he is or has been married and also allow the person to disclose any such communication notwithstanding that the person who made it does not consent. This is an infringement of basic human rights and can also be considered as contravening the principles of natural justice which should be observed as part of RoL. An analysis of the substitution for sections 20, 22 and 24 shows further evidences of deviations from the RoL principles. For example, the substitution of the subheading 'Documents seized during raid or in the course of Investigation' to 'Documents or things seized or howsoever obtained' is a clear breach of the principle of natural justice. Initially, the section only made documents seized during a raid or in the course of investigation admissible as evidence but in the amendment, all documents or things seized or howsoever obtained whether before or after a person has been charged for a security offence and the contents of the documents or things shall be admissible as evidence. The substitution of Section 22 is made to ensure alignment with the changes in Section 20. The substitution of Section 24 also widens the ambit of admissibility of intercepted communication and monitoring, tracking or surveillance information. This further erodes principles of basic human rights of privacy for interception done before or after a person is charged is admissible at his trial evidence. The analysis of these key amendments indicates evidences which show that basic principles of RoL as advocated by Raz have not been upheld.

\section{CONCLUSION}

According to Yap ${ }^{75}$ Malaysia relied on a number of laws to support its counter terrorism efforts, of which the ISA 1960 was the most prominent prior to its repeal. He went to add that the ISA 1960, along with much of Malaysia's security apparatus, is a legacy of its colonial past, and was initially used to combat the communist insurgency during the Emergency period (1948-1960). Further from the 1990s onwards, it was also used to counter emergent militant groups with radical or extremist ideologies. After 9/11, ISA 1960, with its emphasis on preventative detention, drew comparisons to the United States' PATRIOT Act, the United Kingdom's Anti-Terrorism Act and other counterterrorism

75 Sean Yap, "Counterterrorism in Malaysia after the ISA Repeal: Assessing Capacity to Combat Threats Counter Terrorist Trends and Analysis," Journal of the International Centre for Political Violence and Terrorism Research (July, 2013): 1-16. 
legislation around the world. Yap concludes that while the repeal of ISA 1960 has slightly weakened Malaysia's counterterrorism capacity, the security apparatus in place, together with the new law that was passed to replace ISA 1960 are capable of ensuring that Malaysia's capacity to combat terror has not been severely undermined. ${ }^{76}$

In contrast, according to Ding Jo-Ann, ${ }^{77}$ the definition of who may be arrested under SOSMA 2012 remains too broad. The definition of "security offence" includes committing Acts "prejudicial to national security and public safety". She went on to say that such a broad definition allows the government to deem, for example, the Bersih 2.0 rally, possession of Che Guevera T-shirts and Seksualiti Merdeka, a sexuality rights festival as national security threats. This concern is also addressed by SUARAM which asserts that detention without trial and incommunicado detention remains on the statute books as the Internal Security Act 1960 was replaced by the Security Offences (Special Measures) Act 2012. Further, it states that freedom of assembly is now governed by a restrictive legislation; the freedom of expression has been restricted by the introduction of s.114A Evidence Act 1950; a program that was supposed to regulate non-citizens was abused by government cronies through fraudulent employment agencies. ${ }^{78}$

The Bar Council went on to list a number of concerns with regards to SOSMA 2012. Firstly, the provisions of SOSMA 2012 and amendments to the Penal Code, Criminal Procedure Code and Evidence Act 1950 introduced in July 2012 have significantly weakened fair trial protections by permitting evidentiary presumptions against an accused to be made by the courts and shifting the evidential burden to the accused to prove innocence. Secondly, interception of communications can be undertaken by the police without court supervision, and prosecutors may introduce evidence in trials without having to disclose their sources. Finally, even if a suspect is acquitted, detention can now be ordered pending disposal of appeals. Provisions too now exist for use of electronic monitoring devices. $^{79}$ The World Reports 2013 highlighted almost similar concerns. It is reported that provisions in SOSMA 2012 reduce human rights protections, including an overly broad definition of a security offense, allowing police rather than courts to authorise interception of communications during investigations, and permitting prosecutors to conceal the source of evidence and to keep the identities of witnesses

\footnotetext{
$76 \quad$ Ibid.

77 Ding Jo-Ann, "False hope in Security Offences Act".

78 "Malaysia human rights report 2012: Civil and political rights". (SUARAM Komunikasi, 2013), 1.

79 Malaysian Bar Council, "Submission of Bar Council" 1.
} 
secret, thereby preventing cross-examination as well as allowing indefinite detention through a series of appeals with bail disallowed. ${ }^{80}$

In September 2012, Chairperson Tan Sri Hasmy Agam, in a 2 day colloquium with the country's top judges had urged judges to take into account human rights and international conventions in arriving at decisions, even though these were not expressly laid out in law. He also urged the courts to interpret and breathe life into international laws in Malaysian courts, otherwise, it is futile to signify and ratify the said laws. ${ }^{81}$ Citing that these international laws have yet to be encoded into Malaysian laws, as much as judges are facing constraints, they should also be able to ensure that the United Nations Declaration of Human Rights and the Charter of United Nations are taken into account when arriving at decisions. ${ }^{82}$ Despite limiting the extent of the government's powers such as the arbitrary indefinite detention of individuals without charge, SOSMA 2012 including the SOSMA Amendment Bill 2015 and amendments to existing laws in the security apparatus like the Penal Code and the Criminal Procedure Code, still confer on the government broad powers and also makes evidence against suspects more easily admissible. ${ }^{83}$ Thus, it can be concluded from the analysis of the provisions in SOSMA 2012 and the arrests made under the act, there are evidences of breaches of the key principles upheld in the RoL.

80 Human Rights Watch, "World Report 2013," accessed December 12, 2013, http://www.hrw.org/world-report/2013/country-chapters/malaysia?.

${ }_{81}$ Malaysia human rights report 2012: Civil and political rights, 31.

82 Ibid

83 Sean Yap, "Counterterrorism in Malaysia after the ISA Repeal". 
